evidence that the recent debunking of them as a nationalist myth has gone too far. His chief input to the Britishness debate is that biologically and culturally, the Anglo-Saxons were not the first English nation.

Bryan Sykes agrees. In Blood of the Isles, a shorter and less well-illustrated volume supported by a website, he reports on the Oxford Genetic Atlas Project. The added interest is his account of racist scientists such as Robert Knox, who distinguished between the hard-working Anglo-Saxons and the indolent Celts on the basis of hair colour and head size. Sykes is particularly good at demolishing these repugnant myths with his genetic data, although I was alarmed by his impudent daim that "my art is oblivious to the prejudice of the human mind". Historical genetics is just as much an interpretation for its time as the shape of skulls was in the nineteenth century.

So, where does all this leave Britishness? As Sykes says, "this really is the history of the people, by the people. We carry our past in our genes and, as Oppenheimer shows, if we are looking for that common ground where science and education meet, then it was 15,000 years ago when small groups of highly mobile hunters entered a postglacial wasteland. Getting there first, rather than in large numbers, is the key to the dominance of these founders in our British genes, and this applies to both women (mitochondrial DNA) and men (Y chromosome). Gordon Brown's Britishness needs to be extended back by at least 13,000 years from the familiar world of Celts and Romans to consider those who contributed most to our common heritage. A further 700,000 years needs to be added if we are to

\title{
Treasure islands
}

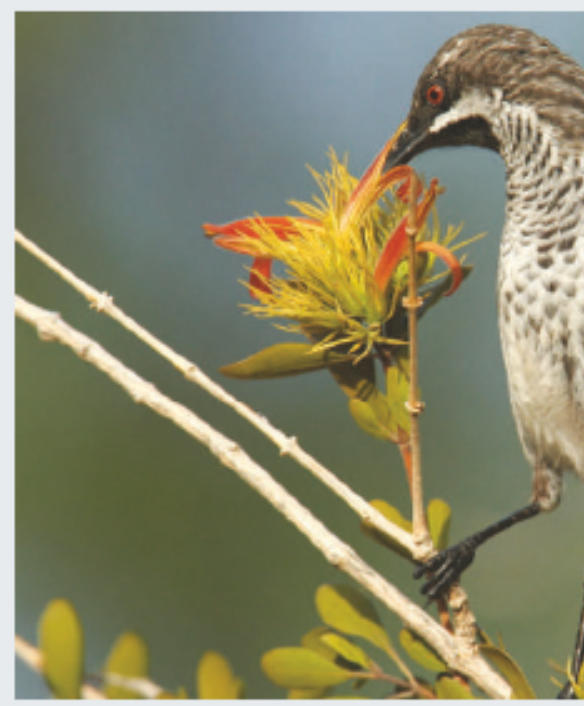

The Socotra islands, in the Arabian Sea off the Horn of Africa, are home to many plant and animal species found nowhere else, including the Socotra sunbird shown here. First settled by man several thousand years ago, this unique environment is populated by a small group of fishers and pastoralists. In 2003,

understand the full evolutionary picture.

And what is the policy implication? This concerns an overhaul of the UK national curriculum, where presently the debate on British identity starts with the Middle Ages. As a result, education is being denied access to scientific progress.

These three books show why we can no

\section{A physics travelogue}

From Clockwork to Crapshoot: A History of Physics

by Roger G. Newton

Belknap Press: 2007. 352 pp. \$29.95,

$€ 19.95, € 27.70$

\section{David Lindley}

If you have just an afternoon to spare for your first visit to the British Museum in London, you have a choice to make. You can trot smartly up and down the corridors, trying to glimpse as many items as possible, or you can choose to linger thoughtfully in a handful of rooms, hoping to absorb a sense of the entire collections scope. In his role as tour guide to the complete history of physics, Roger Newton seems to have had trouble deciding which strategy to adopt. Sometimes he pauses to reflect on the meaning and significance of the most crucial exhibits; at other times he seems determined to march briskly down the centuries, ticking off names and discoveries great and small with bewildering haste. As a result, the truly interesting perspectives that he points out along the way get lost in the confusion.

From Clockwork to Crapshoot begins by defending Aristotle against the bad press he sometimes gets in histories of science. While Plato mused abstractly about the ideal nature of things, Aristotle turned his attention to the 'efficient causes' of empirical phenomena - meaning, in a nutshell, that if something happens, there must be something else that makes it happen. That is a modern philosophy of science, but in his specifics, Aristotle was mostly wrong. It was medieval scholars, rediscovering Aristotle from Arab writers, who treated his writings as a revealed truth, insisting on scrupulous adherence to his incorrect explanations but failing to grasp his style of reasoning.

After dropping in on Roger Bacon, William of Ockham and Nicole Oresme, we're onto Copernicus, Galileo, Kepler and Newton - the beginning of science as we now understand the term. This is familiar territory, and although the author's travelogue is fluent and intelligent, the narrative interest starts to flag. With the basic method of science settled, the story is one of advancing enlightenment on many fronts, and our guide is determined to give at least a brief wave to everyone who contributed. Taken individually, his sketches of Laplace, d'Alembert and Gauss, of Henry, Faraday and Maxwell, and of Rumford, Joule and Clausius, are engaging enough. Thrown at the reader one after the other, they become rather wearisome.

The story picks up again when the author tackles the emergence of statistical mechanics and then quantum mechanics. As the book's title suggests, the evolution away from strict determinism into a world governed by laws of probability marked a tectonic shift in the foundations of science. Quantum theory raised questions about the meaning of physical reality that remain unresolved today. And of late, Roger Newton suggests, Plato is staging a comeback against Aristotle. Now that we have a pretty good understanding of how electrons and other particles behave, we are returning, in attempts to find a 'theory of everything', to the deeper problem of understanding why 